\title{
Pondering Privies: Construction, Use, Reuse, and Other Speculations About Cesspits in the Archaeological Record
}

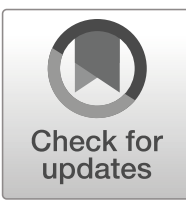

\section{David Smith ${ }^{1}$}

Published online: 4 June 2020

(C) The Author(s) 2020

\begin{abstract}
Should cesspits be excavated and recorded in detail? In the UK, cesspits often are considered 'mundane' and frequently overlooked during excavation or only half-heartedly recorded. This paper explores the biography of cesspits - their construction, use, reuse, and closure/ abandonment, as well as their archaeological investigation and interpretation. What does a cesspit look like? How might we better recognise cesspits archaeologically? By exploring modern NGO guidance and high-quality archaeological studies of cesspits and latrines, we can begin to understand something of the common biography of these features. Comparison between the approach to the excavation/recording of cesspits in the USA with that of the UK also may inform our collective approach to these features at any archaeological site. Perhaps our own assumptions and approaches to the archaeological interpretation of these features may be hindering our understanding of their significance as important records of status and societal behaviour? This paper will conclude by exploring the interpretation of cesspits from two different chronological periods in the UK, outlining entirely different approaches to quite similar data.
\end{abstract}

Keywords Cesspits · Latrines · Archaeological deposition · Interpretation of archaeological features

\section{Introduction}

Deep circular shafts and sub-rectangular pits, both lined and unlined, are a common feature on Mediaeval and Early Post-Mediaeval archaeological sites in the UK (Sabine 1934; Greig 1982; Jervis 2014; Van Oosten 2016; Jeffries 2006; Cessford 2017). This paper suggests that there is a tendency, particularly on developer-funded sites, to not

David Smith

d.n.smith@bham.ac.uk

1 Department of Classics, Ancient History \& Archaeology, The University of Birmingham, Edgbaston, Birmingham B15 2TT, UK 
excavate and record such features at all, or only in limited detail (Jeffries 2006; Cessford 2017). These features often are interpreted as wells or pits that were used for the disposal of domestic rubbish when their active life stopped. As a result any fills within them have limited interpretational value. This paper will take a 'life history' or 'object biography' approach to latrines and other features that may contain cess, in order to explore these issues and hopefully result in a widening in approach and an increase in the extent and detail that they are recorded.

Discussing the 'life history' or 'biographies' of both objects and archaeological features is an idea that has gained some currency in recent years (e.g. La Motta and Schiffer 2001; Bradley and Edmonds 1993; Kopytoff 1986; Tringham 1994; Holtorf 1998; Holtorf 2002; Gosden and Marshall 1999; Immonen 2002; Evans 2003; Berggren 2012; Chapman 2012; Fontijn 2012; Garrow 2012; Edmonds 2012; Jervis 2014), though its overall applicability has been questioned (e.g. Joy 2009; Burström 2014). Central to this concept is the idea that an object's role and use may change or be 'recycled' throughout its life, from production and use, through disposal (e.g. La Motta and Schiffer 2001; Tringham 1994). It also explores how the social context and the role of these objects as 'social actors' change with time and the alteration of the object (e.g. Kopytoff 1986, Gosden and Marshall 1999, Joy 2009, Edmonds 2012 and Burström 2014). 'Object biography' therefore allows a deeper, richer ('thicker'), and multifaceted understanding of an archaeological object (Burström 2014) and identification of the complex histories of a particular object (Mytum 2004; Burström 2014). The life history discussed here is not the 'short' history of La Motta and Schiffer (2001), which emphasises the object's life before burial but a 'long history' that also considers how objects are excavated, recorded, and interpreted (Holtorf 2002; Edmonds 2012).

One issue for this paper is that 'mundane' objects such as 'cesspits' seem to lack any form of obvious social entanglement and, therefore, lend themselves more to the 'bio' rather than 'graphy' of this approach (Edmonds 2012; Burström 2014). However, when we look at the modern sociology, history, and archaeology of these features, this can shed light on their deeper social role and context.

Throughout the paper, the term 'cesspit' is used to collectively denote any pit or feature from archaeological sites that contains human faecal remains and other descriptors, such as, cat holes, straddle trenches, sub-rectangular pits, latrines, and privies, will be specifically defined below.

Table 1 presents the results of a survey of the nature of a range of 'cesspits' which were included in a survey of UK cesspits (Smith 2012), where further archaeological details and implications are discussed. Figure 1 shows the location of these sites.

\section{Life Stage 1: Form and Construction}

Figure 2 depicts the construction of the four main forms of 'cesspits' that are likely to be encountered on archaeological sites. These have been taken from the archaeological record, US Army guidelines for 'field sanitation' (US Army 1945, 2005, 2007), and a range of guidance notes issued by Non-Governmental aid Organisations (e.g. Water Policy International 2001; Department of Water Affairs South Africa - DWAFSA 2002; Jenkins 2005; Grassrootswiki 2010; World Health Organisation - WHO 2010). 


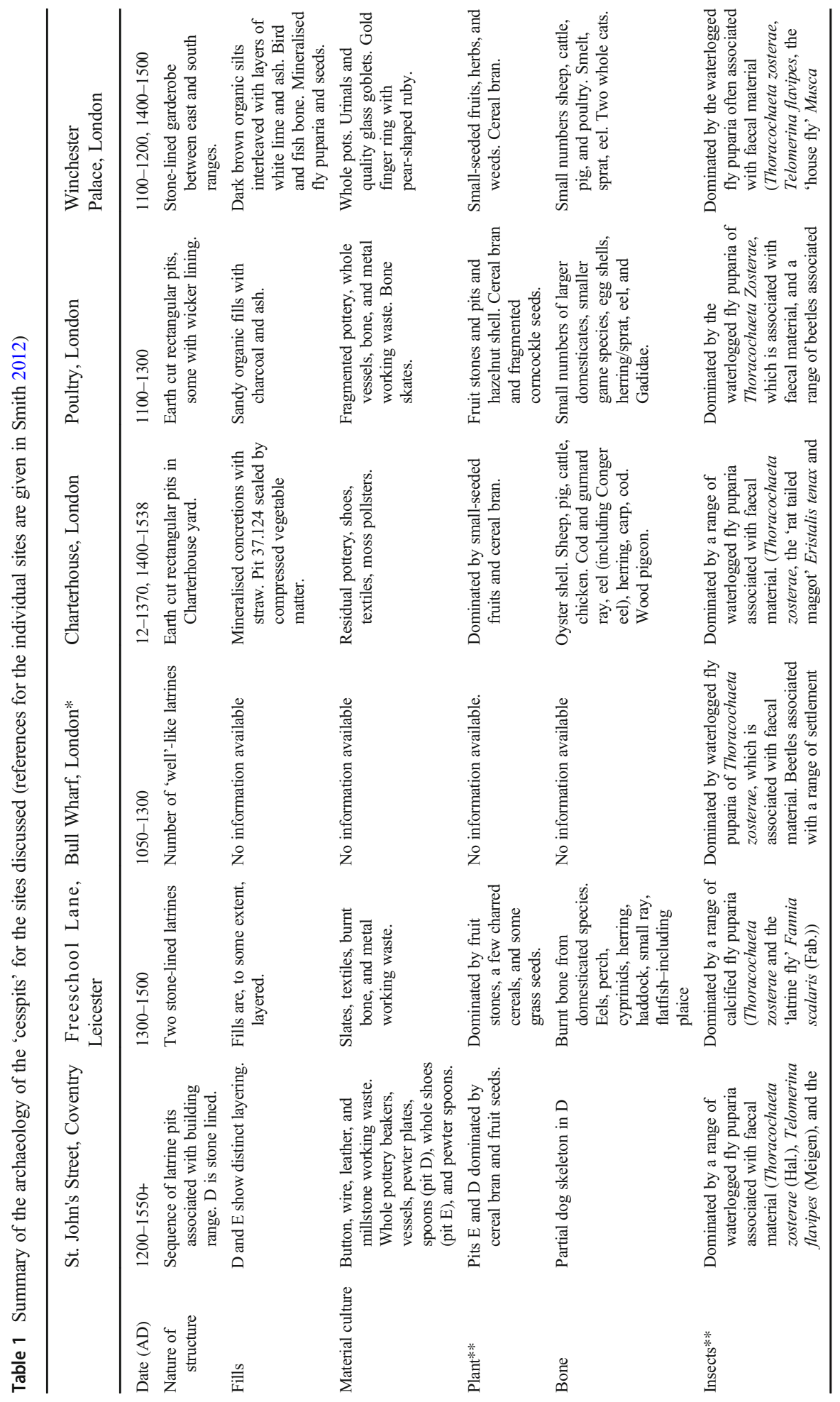




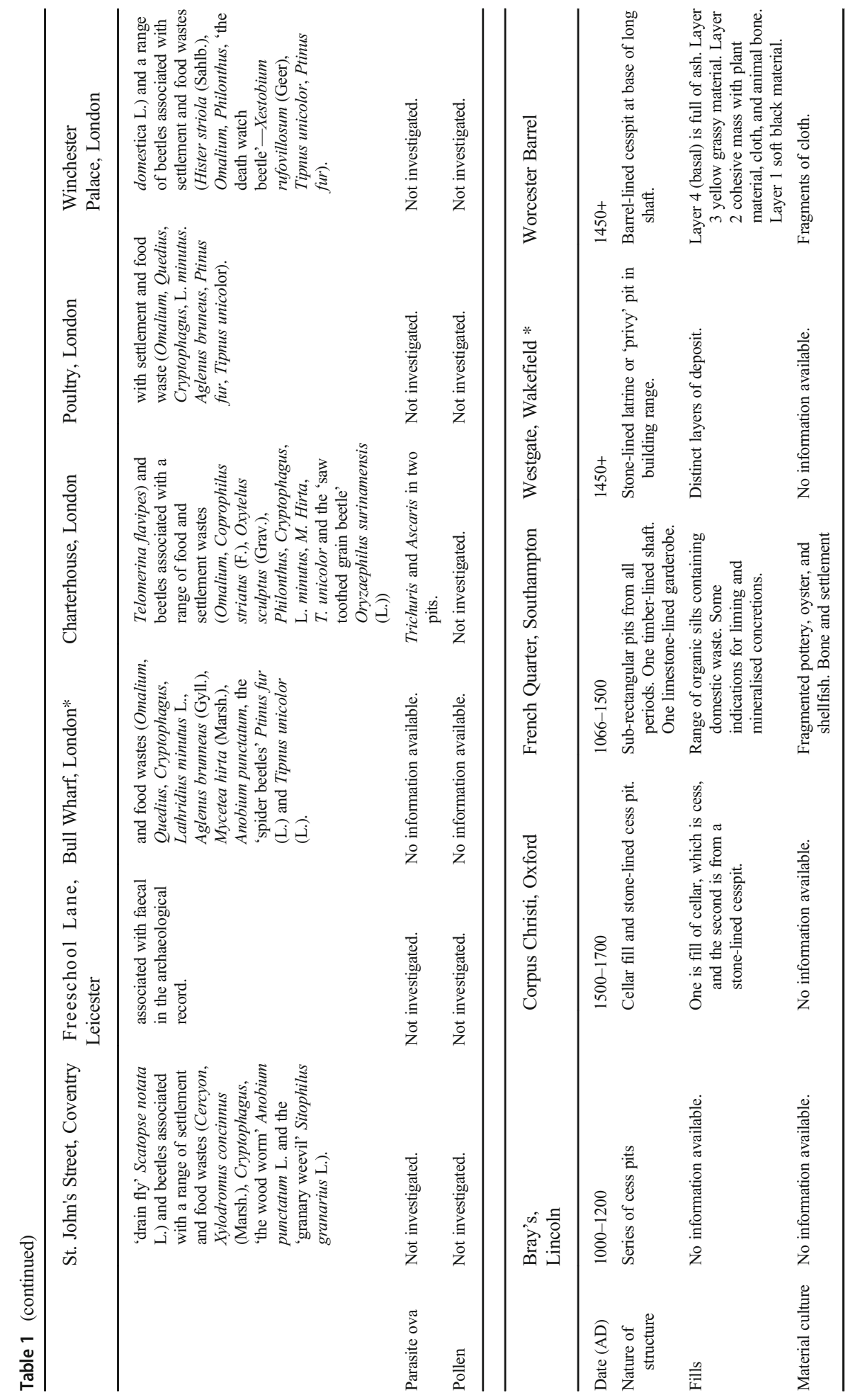




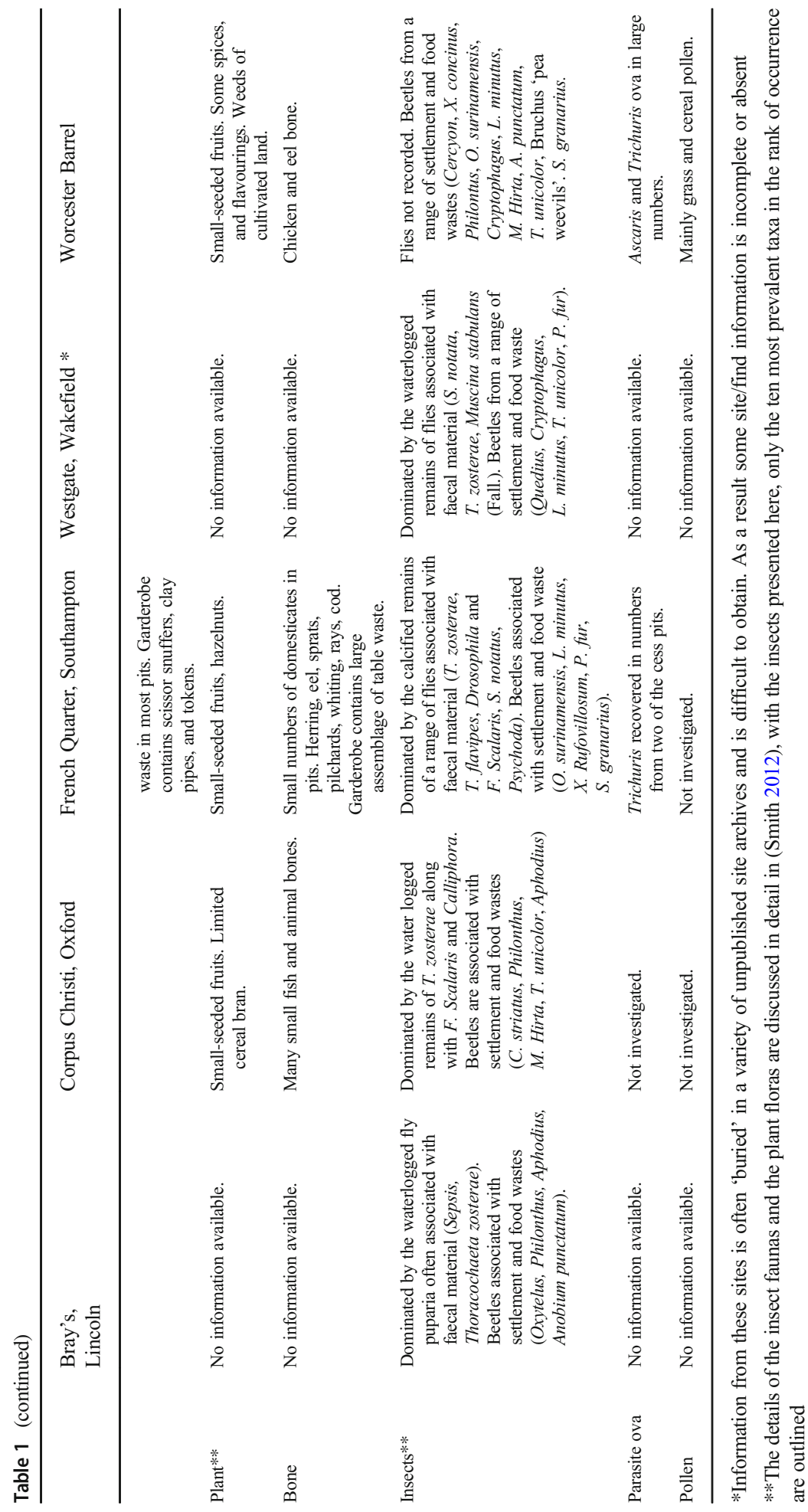




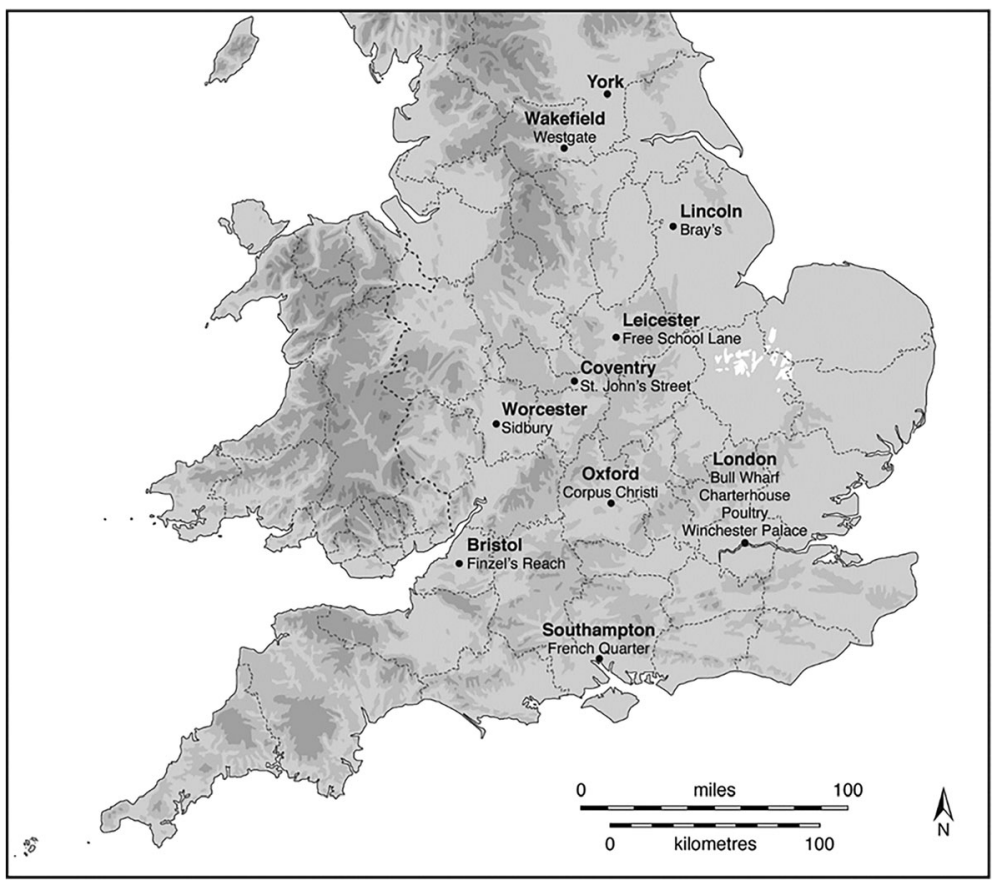

Fig. 1 Location of sites discussed in Table 1

\section{Cat Holes}

The simplest form of cesspit is the 'cat hole'. This is a pit approximately $30-\mathrm{cm}$ deep and 50$\mathrm{cm}$ wide, which is used for open defecation over a short time scale (e.g. Nakagiri et al. 2016) and then covered over with packed earth (US Army 1945, 2005, 2007). In practice, such a small scale, short-lived pit would be difficult to identify archaeologically.

\section{The Straddle Trench}

The US Army uses 'straddle trenches' when they are on short-term bivouacs lasting around 1 week. These consist of open trenches, which are $0.6-\mathrm{m}$ wide by $1.2-\mathrm{m}$ long and around 1-1.5-m deep. They are short-term square cut features that are more prone to collapse than round ones but are easier to dig and, importantly, empty (US Army 2007; World Health Organisation - WHO 2010). Similar defecation trenches are common in new refugee camps, where there is an urgent need for a fast and simple way to dispose of faecal material (e.g. WHO 2010; Solidarities 2017).

Many similar-sized 'sub-rectangular pits', lined or unlined, are excavated from Mediaeval and Early Modern urban sites in the UK. For example, those from twelfth to fourteenth century AD St. John's Street, Coventry (Colls and Mitchell 2012); the London Charterhouse (Barber and Thomas 2002); and the Poultry Site, London (Burch, and Treveil, P. with Keene, D. 2011) (see Table 1). These features all contained a range of biological remains that indicated the presence of cess, stabling, and kitchen waste (Smith 2012). Jørgensen (2006) indicates that similar latrine structures, with removable wooden walls, were common in alleyways in Late Mediaeval Bergen, Norway. 

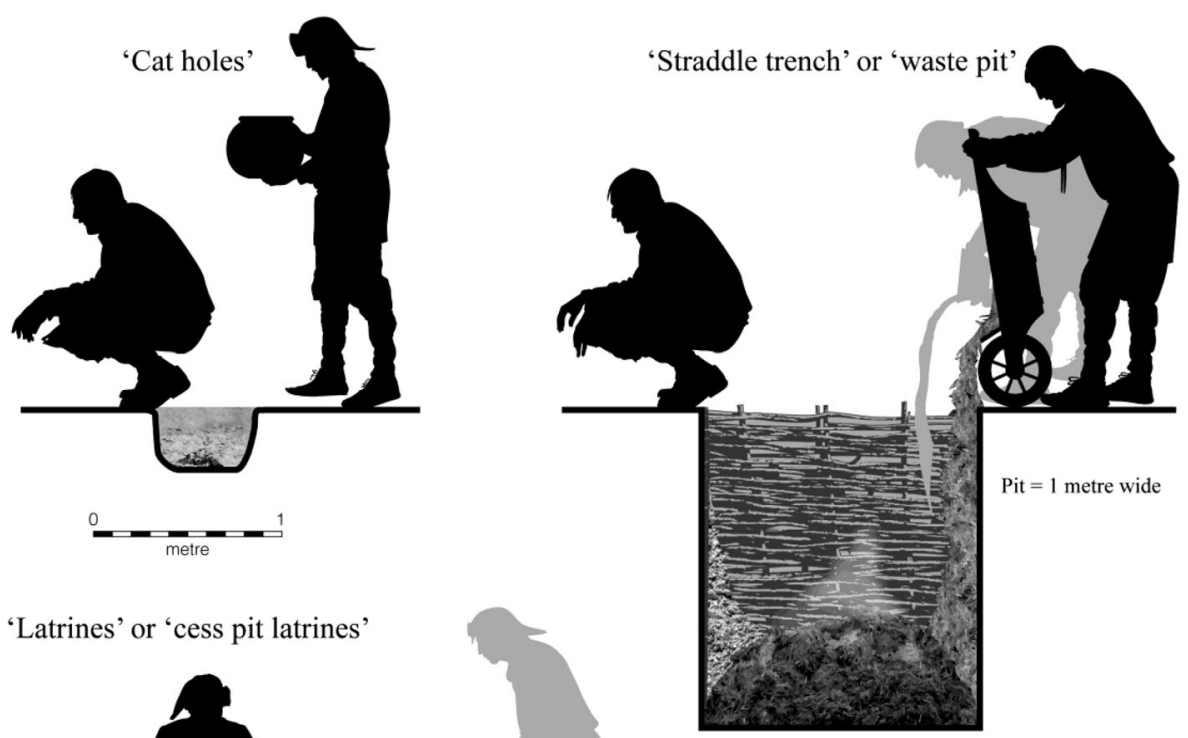

'Latrines' or 'cess pit latrines'

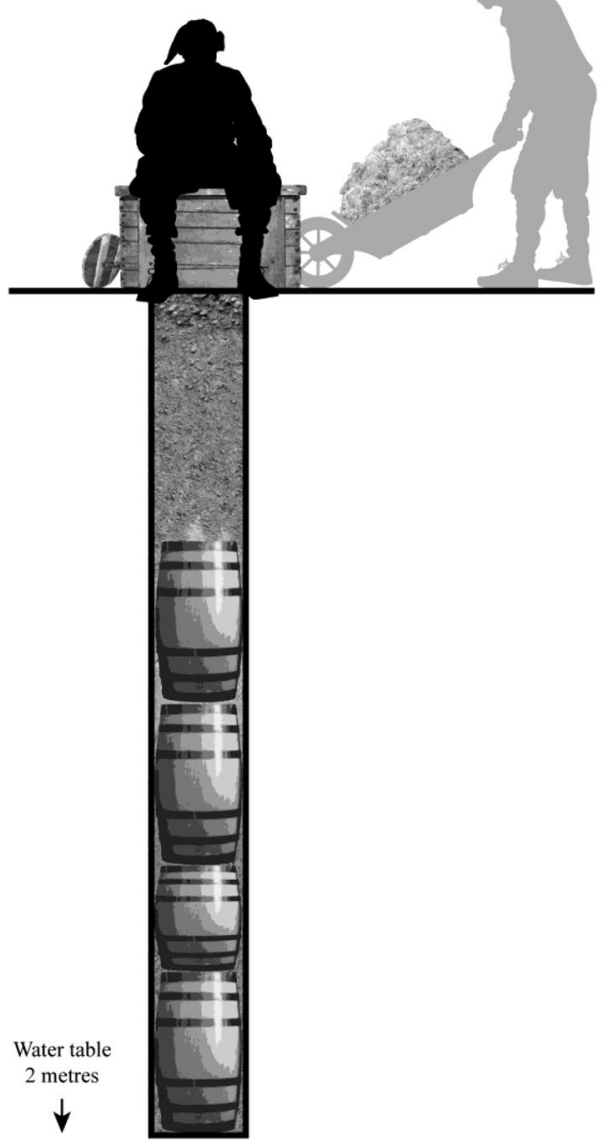

'Simple garderobe'

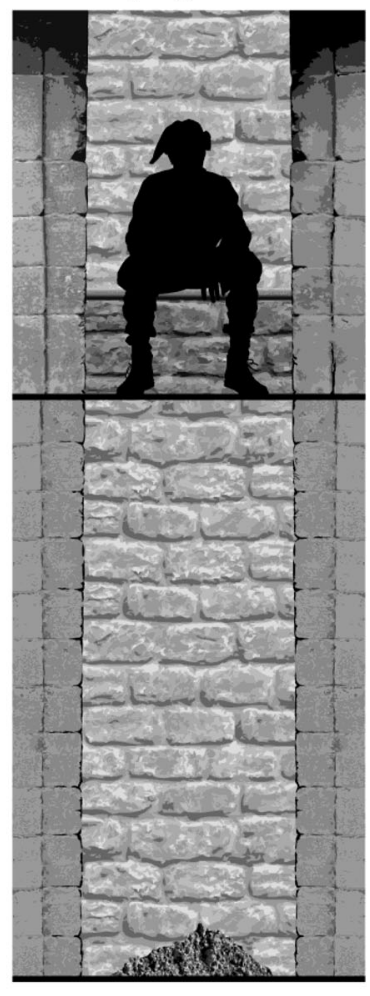

Fig. 2 Possible types of 'cesspits' recovered from the archaeological record

Straddle pit latrines also have been excavated in detail at the site of the St. Johnson's American Civil War prisoner camp (Bush 2000). 


\section{Latrines}

A latrine consists of a dedicated seat and shaft which lead to a pit or pool. Modern guidelines give very specific advice on location and form (e.g. US Army 1945, 2005, 2007; Department of Water Affairs South Africa - DWAFSA 2002; World Health Organisation - WHO 2010): latrines should be constructed at least $100 \mathrm{~m}$ from any food preparation area and down wind and slope from habitation and water sources. Testing of groundwater quality has shown that it declines within 10-20 m of a latrine (Graham and Polizzotto 2013). Interestingly, most mediaeval by-laws dictate that latrines must be at least $2-10 \mathrm{ft}$ from adjoining properties, presumably for similar reasons (i.e. Jørgensen 2006). The pit itself should be $30-60 \mathrm{~cm}$ in diameter for a single seat and $30-120 \mathrm{~cm}$ for a double seat; greater widths are discouraged, since they are prone to collapse (Tilley et al. 2008; US Army 2007; World Health Organisation - WHO 2010). The shaft should be at least 2-3 $\mathrm{m}$ in depth to allow urine and 'grey water' to leach out of the bottom of the pit. The bases of latrine shafts should also be at least $2 \mathrm{~m}$ above the water table to prevent standing water building up in the bottom of the pit (WHO 2010).

Round shafts are recognised to be stronger than square- or rectangular-shaped shafts, particularly in areas where ground conditions are loose or unstable (US Army 2007; World Health Organisation - WHO 2010). Where ground conditions are less stable, or the pit is very deep, the shaft should be lined with planking, bricking, supports, or concrete rings to prevent collapse (US Army (2007; World Health Organisation - WHO 2010). This material needs to be permeable in order to allow water to leach out, which prevents latrines from overflowing or stagnating.

Modern latrines are traditionally covered by a wooden or brick outhouse. This is not just for privacy, it keeps ground and rainwater out of the pit, preventing overflow and fouling (Nakagiri et al. 2015, 2016). Such 'houses of easement' also should be impervious to light or have a close-fitting lid, since most flies are phototrophic (light favouring) and are not attracted to permanently dark areas (Nakagiri et al. 2015, 2016).

A range of round deep shafts, often reinforced by stone, wickerwork, or barrel linings, is common at a number of mediaeval archaeological sites (Hall et al. 1988; Addyman 1989; Hall and Hunter-Mann 2002). An archaeological example of a barrellined shaft from Finzel's Reach, Bristol, is illustrated in Fig. 3. Some lined pits were quite complex and needed skilled construction, for example, the 'bottle'-shaped brick pits from the Netherlands (Van Oosten 2016).

\section{Privies and Garderobes}

Privies consist of a straight drop over the edge of a building, usually into open water (hence, the continental proverb for something dead obvious: 'it hangs like a privy over a ditch'). Garderobes are enclosed, internal 'rooms' that 'drop' via a shaft or chute into an internal stone-lined 1-2-m-deep pit, which is capable of being emptied. Examples of excavated privies or garderobes occur at Winchester Palace, London; St. John's Street, Coventry; Corpus Christi College, Oxford; Tenement 237 in the French Quarter, Southampton; and at Westgate, Wakefield (see Table 1). All of these stone-lined pits contained elements of the 'cesspit indicator package', which was outlined in Smith (2012). Examples of similar features also can be found in mediaeval York, England (Addyman 1989), Bergan, Norway (Jørgensen 2006), and towns in the Netherlands (Van Oosten 2016). 


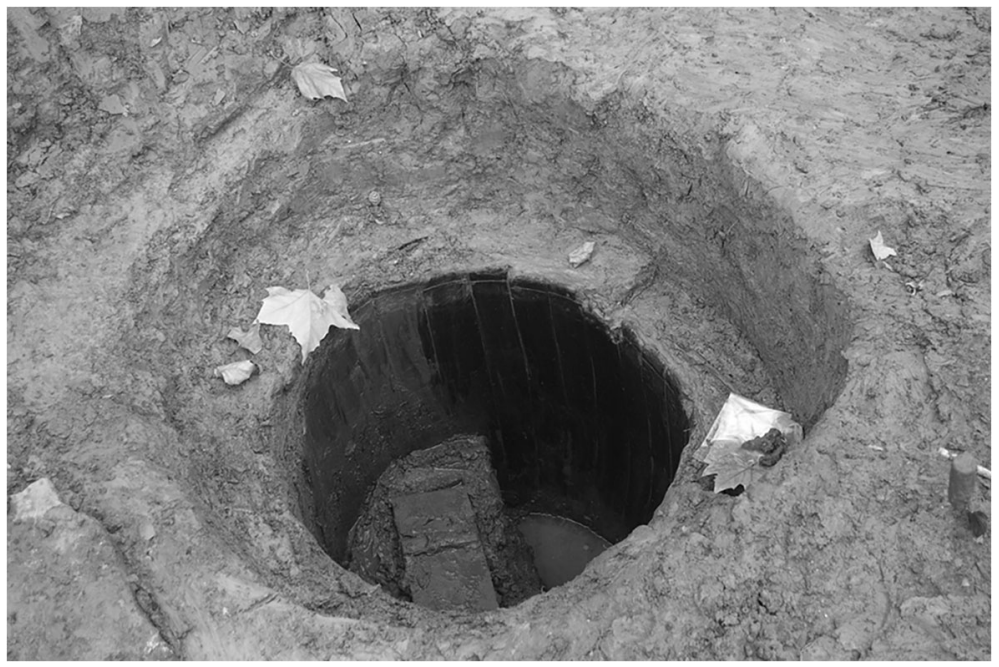

Fig. 3 A barrel latrine from Finzel's Reach, Bristol

\section{Life Stage 2: Use and Maintenance of Latrine Pits}

\section{Potential Lifespan}

An assumption often made is that latrine pits have short lives and do not warrant complex or time-consuming construction. However, latrine pits can have a prodigious capacity and a very long life, especially if maintained well. The US Army suggests that the average company unit (roughly 200 persons) will produce only $30 \mathrm{~cm}$ of 'fill' a week. NGOs suggest that a single person produces 'solids' at a rate of 40-60 1 per year (90 1 if 'dry cleansing materials' are included in this figure-Tilley et al. 2008; Grassrootswiki 2010; World Health Organisation - WHO 2010, Nakagiri et al. 2016), which compacts by $50-80 \%$ after deposition (Nakagiri et al. 2016). The World Health Organisation - WHO (2010) indicates that a 1-m wide and 2-3-m-deep pit will serve a family of 6 for 5 years. Deep, well-maintained, and 'composting' latrine pits could last as long as 20 years (Water Policy International 2001; Tilley et al. 2008; Grassrootswiki 2010; Nakagiri et al. 2016). This could effectively turn the construction of a latrine pit into a generational 'event' that would warrant considerable investment, labour, and even celebration. On the other hand, the life of a cess pit could be extended by periodic emptying. In seventeenth Century Breda, the Netherlands, it is estimated that the pits were cleared every 4.5 years on average (Hummperetz 2010).

\section{Prolonging the Life of the Pit and Encouraging 'Self-Sanitation' by Addition of Organic Matter}

Maintaining a latrine pit simply involves controlling what goes down the pit and avoiding a number of sanitary risks. Groundwater contamination can be avoided by ensuring that only urine enters, with washing and cooking water poured elsewhere. The bottom of new latrine pits should be lined with a mat of hay or straw, which retains urine in the pit until it can break down (Calvert 2014; World Health Organisation - 
WHO, 2010). Notably, the lowest level of the Worcester barrel latrine contained 'yellowish crusty material with grassy matter' (Greig 1981). Modern guidelines suggest that periodic addition of vegetation, cooking waste, ash, and soil can be beneficial throughout the life of a pit. This absorbs liquids, raises the $\mathrm{pH}$ of the pit, and encourages the breakdown of faecal material by adding a source of carbon to a nitrogen-rich environment. This biological breakdown should raise the temperature of the pit to above $50{ }^{\circ} \mathrm{C}$, which effectively makes it self-sterilising and prevents the proliferation of diseases (i.e. cholera, dysentery, typhoid, internal parasites, etc.) (Del Porto and Steinfeld 1999; Jenkins 2005; Calvert 2014; Morgan 2007; World Health Organisation - WHO, 2010). This also has the advantage of reducing the volume of material present, which prolongs the life of the latrine pit (Del Porto and Steinfeld 1999; Water Policy International 2001; Jenkens 2005; Morgan 2007; Tilley et al. 2008; World Health Organisation - WHO, 2010).

\section{Preventing Fly (Diptera) Infestations}

Flies and maggots can represent a serious problem if they occur in latrine pits, since they are efficient vectors for disease (K.G.V. Smith 1973, 1989). Infestations of cess pits can be avoided by:

- having a tight-fitting lid or outhouse (Nakagiri et al. 2016).

- stopping the development of breeding conditions by adding carbon-rich organic matter such as dry vegetation and kitchen waste (Tilley et al. 2008; Grassrootswiki 2010; Nakagiri et al. 2016).

- adding ash and dry soil to the pit to bury the problem and to alter the environment in the pit stopping future fly infestation. Ash may also directly kill insects by absorbing the lipid from the waxy surface of the exoskeletons, which may lead to dehydration (Hakbijl and De Groot 1997; Panagiotakopulu 2000).

- adding a spoonful of 'lime' $\left(\mathrm{CaOH}, \mathrm{Ca}(\mathrm{OH})_{2}\right.$, or $\left.\mathrm{CaCO}_{3}\right)$ after each defecation also is recommended for similar reasons. Large-scale infestations can be treated by adding larger volumes of lime (Calvert 2014; Morgan 2007). However, the US Army does not regard 'liming' as particularly effective, preferring to 'burn the pit out' (US Army 2007-there is a rather intriguing guidance note that aviation fuel should not be used because of the danger of explosion).

Some of the better recorded and preserved archaeological 'cesspit' fills may have formed in a similar way. Several contain alternating deposits of cess, vegetation, hay, and ash leading to a layered or 'structured' nature (e.g. the Worcester 'barrel' (Greig 1981), the latrine at Winchester Palace (Seeley et al. 2007), and the 'cesspits' at Melbourne Street, Southampton (Jervis 2014)). Liming has certainly been recorded from straddle trenches and latrines in the USA, where its periodic use led to 'lime layering' (Carnes-McNaughton and Harper 2000).

There is circumstantial evidence for the addition of lime from the archaeoentomological evidence. Many archaeological latrine pits contain fly puparia that have been preserved by mineral replacement. These are sometimes encased in a white powdery material that potentially could be lime (see Caruthers and Smith 2020). Additionally, at Freeschool Lane, Leicester (Smith 2009a); Causeway Lane, Leicester (Skidmore 1999); and the French 
Quarter, Southampton (Smith 2009b), the fly puparia were all killed at the same developmental stage often with the 'shadow' of the developing adult fly contained in the puparia. Skidmore (1999) has suggested that the occurrence of a 'sudden kill off events' like this could be linked to the intentional liming of these features.

However, analysis of mineralised fly puparia has shown that some are preserved by calcium phosphate replacement rather than calcium carbonate and, therefore, could not result from liming alone (McCobb et al. 2004; Caruthers and Smith 2020). Calcium phosphate replacement also occurs in mildly acidic latrine pits which contain abundant organic matter, bones, and shells (McCobb et al. 2004). Rebecca Nicholson (pers. comm. - Oxford Archaeology) also has suggested that mineralisation seems to go hand in hand with the recovery of substantial numbers of fish bone and oyster shell from these latrine pit features.

\section{Emptying of Latrine Pits}

Latrine pits can be periodically emptied, with their contents usually removed for use as 'night soil' within fields or gardens. In the Netherlands, latrine pits were expected to be emptied at the expense of the landlord, rather than the tenant, and the cost of emptying a latrine pit was equivalent to 2 to 3 months of rent (Van Oosten (2016). In the UK, the role of 'dong farmers' or 'rakers' who collected cess and emptied cesspits was a recognised, organised, and profitable trade. Labourers who cleared latrines in the Mediaeval and Post-Mediaeval periods were paid up to four times the average worker's salary (Sabine 1934; Keene 1982; Signe Morrison 2008; Van Oosten 2016).

\section{Life Stage 3: Closing and Abandonment of Sub-Rectangular Latrine Pits}

The closing of latrine pits, either to allow the material in them to breakdown to compost or to end the pit's use, also requires planning. The US Army (2007) and several NGOs recommend that latrine pits should be sealed once the ordure reaches within $30 \mathrm{~cm}$ of the top of the shaft. The fill should be sealed with several $8-\mathrm{cm}$ thick layers of compacted earth or clay to prevent access or egress of flies. The nature of sealing deposits for latrine pits is not often explored in the archaeological record, since many of these features often are severely truncated. But these have been recorded for several intact latrine pit features at the St. Johnston's prisoner of war camp and the pits from Portsmouth, New Hampshire, USA, for example, which all were sealed with clay (Bush 2000; Wheeler 2000).

Where the pit has been fully emptied or is only partially filled, settlement debris and other waste can be added to 'level out'. This clearly seems to have been the case at eighteenth century Spitalfields in London, nineteenth century Lambeth and the post-1750 deposits from the Grand Arcade, Cambridge, in the UK and seventeenth century Breda, the Netherlands. Here, the upper fills of many pits contained a range of unbroken household items, which seem to represent a single large dump deposit or 'clearance group' (Jeffries 2006; Cessford 2017; Hupperetz 2010). How to disentangle such deposits from any cess-rich fills will be discussed below. 


\section{Life Stage 4: 'Cesspit' Excavation and Recording: an Inconstant Approach}

Craig Cessford (2017), Jeffries (2006), and Dave Evans (2010) have suggested that post1750 deposits, including latrine pits, from urban towns in the UK are generally ignored by archaeologists. Cessford (2017) argues that this results from the priority given to earlier and 'more exciting' Roman or Saxon deposits on large multi-period sites. This is especially true where excavation is short and limited, in terms of time, funding, and area. There is a tendency to suggest that the role and function of features, particularly shaft latrines and pits, is 'mundane' and fully "understood', especially when they are from historic periods, and their use is well-documented (Cessford 2017). Smith (2012, Table 1) presented a survey of 49 Mediaeval 'cesspit' features from $11 \mathrm{UK}$ archaeological sites and found that the quality of the archaeological work at these sites varied greatly. Detailed context-level description was limited to St. John's Street, Coventry (Colls and Mitchell 2012), and Winchester Palace, Southwark (Seeley, Phillpotts and Samuel 2007). Other sites usually were limited to feature-level recording and discussion or even vaguer ('five cesspits were found in the northern sector of the site'). The error in this approach is demonstrated by the wealth of information and interpretation shown in Cessford's (2017) work on the interpretation of large pottery assemblages in post-1750 AD Cambridge and Jeffries' (2006) ability to link changing patterns of archaeological deposition in Lambeth to the local history of sanitary improvement.

This lack of interest in 'cesspits' is not seen in the archaeology of the USA. Here, it is common to concentrate on the excavation of eighteenth to nineteenth century 'privy' deposits. They are considered to be the features which produce the widest range of preserved material culture on site. In the USA, it is common to use 'privy' contents to examine patterns of changing food supply, consumer behaviour, waste disposal, and social stratification. Often, these interpretations are related to detailed historical or settlement studies (for example Bush 2000, Carnes-McNaughton and Harper 2000, Crane 2000, McCarthy and Ward 2000, Peña and Denmon 2000, Stottman 2000, Wheeler 2000). To be fair, these US sites often have a shorter period of archaeological deposition than those in the UK, and there is not the perceived need to 'hack out' such features to get down to earlier (and 'more exciting') archaeology.

\section{Life Stage 5: Environmental Archaeological Analysis of 'Cesspits'}

The issues discussed above that have led to limited excavation of 'cesspits' also seem to affect the sampling and analysis of any environmental remains from these features. Over the last 25 years, the author has been told, many times, that 'late' deposits and 'cesspits' in the UK do not warrant investigation since 'it is only a cesspit and we do not have the money in the budget for that'. Smith's (2012) comparative study (see also Table 1 here) demonstrated that the range and quality of the environmental archaeology undertaken from these features were also highly variable. Often, several techniques (pollen, parasite ova, fish bone, etc.) are overlooked. In contrast to this rather lackadaisical approach, Smith (2012) demonstrated that a consistent use of a 'indicator package' for cess, which employs the full range of environmental and archaeological evidence, can lead to a detailed understanding of the depositional history, use, and nature of these features. 


\section{Life Stage 6: Interpreting the Depositional History of Archaeological 'Cesspits'}

\section{Are 'Sub-Rectangular Pits' More than Just 'Rubbish Disposal'?}

Many 'sub-rectangular pits' (see Table 1) contain animal, plant remains, and associated material culture that indicate the presence of considerable amounts of human cess, food waste, and other domestic rubbish. Obviously, the fills of such pits can have a primary function for rubbish disposal, and indeed, after $1750 \mathrm{AD}$, this may have been their main purpose (Jeffries 2006; Cessford 2017). The fill of these pits also can represent the unlawful, but convenient, disposal of household matter and kitchen waste into existing pits (an ancient form of fly tipping-Evans 2010). At Edgbaston and Park Street, Birmingham, and at Finzel's Reach and Redcliff Street in Bristol, tanning pits were reused for exactly this purpose (Patrick and Ratki 2009; Jones 2010; Smith 2010). Certainly, given the number of civil complaints concerning illegal dumping of household wastes in Mediaeval London and other towns, such activity must have been common (Sabine 1937; Jørgensen 2006).

Jørgensen (2006), Evans (2010), and Ciecieznski (2013) have suggested that these pits also could have acted as temporary storage for the accumulation of 'night soil', before being sold on to farmers as fertiliser (i.e. Sabine 1934; Jørgensen 2006; Signe Morrison 2008). Certainly, this profitable industry would have needed infrastructure to support it. Greig (1982) has suggested that most sewage and waste from Mediaeval towns probably ended up being disposed of in this way rather than by burial on site.

\section{When Is a Well Not a Well?-When It Is a Latrine!}

On several Mediaeval sites, deep barrel-lined shafts have been interpreted as wells rather than latrines (e.g. Addyman 1989). The author also had this view expressed to him during a number of site visits over the years. It is a very common interpretation for this kind of feature that occurs on context and feature report forms. The assumption seems to be that such a complex construction method would not be warranted for such a short-lived, 'mundane' feature as a latrine, whereas the more 'valuable' well would require such effort/expense.

There are historic records that clearly demonstrate that these barrel-lined features are not just 'wells'. Sabine (1934), Evans (2010), and Ciecieznski (2013) relate a report from The Calendars and Letters books of the City of London from August 1278, which clearly demonstrates that barrel construction was used for both wells and latrine pits

...the said Stephen de Harewes had caused to be made within the courtyard of his house, for the purpose of a privy (cloacam), of a depth of five casks, in which new wine had been kept ...

Sharpe 1900: 277.

The use of barrel lining as an alternative to constructing brick-lined latrine pits is also mentioned in town by-laws for Leiden and Haarlem in the Netherlands during the sixteenth century (Van Oosten 2016). 
Lastly, and perhaps most tellingly, many of the fills from the 'cesspits' in Table 1 contain a range of insects and plants that are particularly associated with cess in the archaeological record (i.e. Osborne 1983; Smith 2012) rather than the range of taxa that are normally recovered from open wells (e.g. Coope and Osborne 1968; Buckland 1980; Kenward 1978; Hall et al. 1980; Simpson 2001). In particular, this also is the case with the basal samples from these features. Evan's (2010) survey also suggests that the environmental evidence recovered from many such features indicates that the primary fill was cess.

\section{The Contents of 'Cesspits': Primary Deposition? or Reuse/Dumping?}

During the preparation of this paper, several readers have raised the issue of whether the fills of shaft features are primary (i.e. material incorporated during their use) or result from secondary dumping (i.e. deposition once the features fell out of use). If the latter scenario was the case, the archaeological contents of the features might not match their original use. We have already discussed above how the environmental evidence from many deep, circular shafts demonstrates that their primary use predominantly was the disposal of cess.

However, the separation of primary and secondary fills remains difficult for many archaeological deposits, such as, sub-rectangular pits. One solution is to consider the nature of the finds recovered. At several sites in the USA, the primary fills of latrines (the cess) was looser in texture and contained mostly small items and remnants of everyday life. The secondary fills (final dump deposits) contained larger items, which were comprised of sets of associated material (e.g. a whole dinner services) (Bush 2000; McCarthy and Ward 2000; Wheeler 2000). Jeffries (2006) and Cessford (2017) have similar sets of material from the secondary fills of early modern pits in London and Cambridge in the UK and Hummperetz 2010from Breda, the Netherlands. These also were interpreted as single episodes of 'dumping' or 'clearance' deposition. Unfortunately, if we are to sort out the nature of deposition in these features, it requires context-level recording, along with a multi-proxy approach to the material culture and environmental archaeology (as urged by Jeffries (2006), Evans (2010), and Cessford (2017).

\section{Life Stage 7: Archaeological Interpretation and the Social Life of 'Cesspits'}

It was suggested above that 'cesspits' do not really lend themselves to social interpretation, interpretive, or experiential archaeologies. As 'mundane' features, we usually find ourselves thinking more of the 'bio' rather than the 'graphy' (see Edmonds 2012) and tend not to consider social interpretation or how we, as modern archaeologists, consider these futures. However, there are reasons to think that these features may not be as inconsequential as we like to think. Certainly, a number of studies from the USA clearly show that the structure and contents of latrine fills can be used to construct detailed interpretation, which can cover use, consumer histories, and changing patterns of social stratification (e.g. Crane 2000; McCarthy and Ward 2000; Peña and Denmon 2000; Stottman 2000) 


\section{Social Norms and the Use of Latrines}

A range of anthropological and sociological evidence suggests that the disposal of faecal material is laden with cultural symbolism and meaning. Sabine (1937) and Douglas (1966) irrefutably established that faecal material, and its disposal, can be central to ideas of taboo and ritual. Recently, a series of studies have explained why public health projects in Sub-Saharan Africa and South East Asia fail to encourage the adoption of latrine pits over open defecation. Social and ideological concerns such as caste (social status), separation of the sexes, the need to cleanse 'moral pollution', purity laws, and issues of decreased social contact are often more important factors in any decision on how to deal with human excrement than hygiene alone (Sara and Graham 2014; Routray et al. 2015). Conversely, one of the most successful campaigns in rural Benin deliberately identified latrines as material expressions of status, wealth, family love, and 'modernity' (Jenkins and Curtis 2005). It would seem, therefore, that the decision to make and use a latrine may be as socially embedded and dependent on social norms as any other activity. Perhaps we should think about what these 'norms' could be? and how they might be marked in the archaeological record? One added consideration that really warrants further investigation is whether Roman and Mediaeval cess pits are a rural, as well as an urban, phenomenon.

\section{Assumptions About the Archaeological 'Value' of Deep Shafts from Different Periods}

In addition to the tendency to 'hack down' to the 'real' archaeology, another unconscious bias may be at play, which prevents detailed excavation of Mediaeval and early modern shaft/sub-rectangular pit deposits. They universally are perceived as resulting from practical (for which read 'boring') day-to-day activities, whereas prehistoric, and to some extent Roman, deposits often are seen to result from 'structured', 'special', and 'interesting' behaviour. An example of this issue is given below when the interpretation of the shaft pits from Roman Dorchester (Woodward and Woodward 2004) is contrasted with those from Early Modern Winchester Palace, London (Seeley et al. 2007).

There are many indications for the occurrence of a multitude of small scale, often highly domestic, ritual behaviours in Mediaeval and Early Modern UK (e.g. finds of mummified cats, shoes, and 'builders' marks' in buildings). There also is considerable historical evidence indicating a strong social, 'scatological', and symbolic interests in waste and faecal material during the Mediaeval and Post-Mediaeval periods (e.g. Signe Morrison 2008). This could all be expressed through 'ritual behaviour' and via medium of material culture, particularly when 'cesspits' are created, used, and sealed.

\section{Reconstructing the Social Role of Deep Shafts: an Example of Some Interpretative Pitfalls}

An example of how similar features can be viewed differently between two periods may be instructive. In a detailed and persuasive re-examination of a series of Roman square shafts from Greyhound Yard, Dorchester (Durnovaria), Woodward and Woodward (2004) suggest that these represent mundus town foundation deposits into which the offerings of the 'first fruits' were cast. This interpretation is based on the 
assumption that the contents and the fills of the shafts result from 'structured deposition'. 'Structured deposition' is a useful and established concept in archaeology (i.e. Richards and Thomas 1984; Hill 1995; Thomas 1990, 2012; Garrow 2012), which holds that the repeated 'patterning' of archaeological deposits is not accidental, or the result of repetitive mundane activity, but represents an 'everyday', low-scale, form of ritual deposition (Hill 1995; Garrow 2012).

It may be informative to contrast the 'structured deposition' interpretation seen at Dorchester to that from an essentially similar set of archaeological fills and material culture from a square(ish) shaft, but from sixteenth century Winchester Palace, London (Seeley et al. 2007). In this case, the deposit was interpreted as a privy fill, containing additional settlement waste. Table 2 presents a detailed comparison of the archaeological and environmental remains recovered between Roman Greyhound Yard, Dorchester, and Mediaeval Winchester Palace, London. Notably, at Dorchester, Woodward and Woodward (2004) believe that these remains indicate structured deposition, whereas at Winchester Palace, Seeley et al. (2007) did not consider the deposit to be 'structured' at all.

Why this discrepancy in the two sets of interpretation? It must be down to the difference in the approach to the archaeology of the two periods discussed above and the Woodwards' commendable willingness to open up their study to a wider interpretative framework.

It has been stated several times in this article that if we are to gain a more rounded interpretation of latrines and other 'cesspits', we must excavate and record them in detail and examine the full range of physical and biological evidence available. Unfortunately, for the Woodwards, their 2004 paper did not really consider the information from the environmental archaeological studies recovered from these features that was published in their earlier site excavation monograph (Woodward et al. 1993). Here, there is a clear evidence for the presence of cess in these shafts. For example, the mineralised coprolites (Allen 1993) and mineralised plant remains which are 'mostly common food plants as might be expected in a cesspit' (Jones and Straker 1989, 1993: 349), and the presence of a range of domestic animal and fish bone, which can be interpreted as food waste (Maltby 1990, 1993; Hamilton-Dyer 1993). Regardless of any ritual role these shafts may have had, this biological evidence irrefutably suggests that they also were used to dispose of cess and table waste at some point.

Another problem for the Dorchester Shafts is that the proponents of 'structured deposition' rightly urge that any association of material in the features of interest must be 'beyond the normal' for the rest of the site (e.g. Hill 1995; Garrow 2012). At Greyhound Yard, Dorchester, many other features are interpreted by the excavators as 'utilitarian', but they also contain the same range of archaeological material as were seen in the 'ritual deposition' shaft (Smith and Davies 1993; Maltby 1990, 1993; Jones and Straker 1989, 1993; Rogers 1993; Woodward et al. 1993).

\section{Conclusions}

How we choose to consider and interpret any deep circular shaft or sub-rectangular feature from archaeological site is complex. This paper argues that there is more to 'cesspits' than the mere disposal of faecal material. Their construction, use, longevity, 


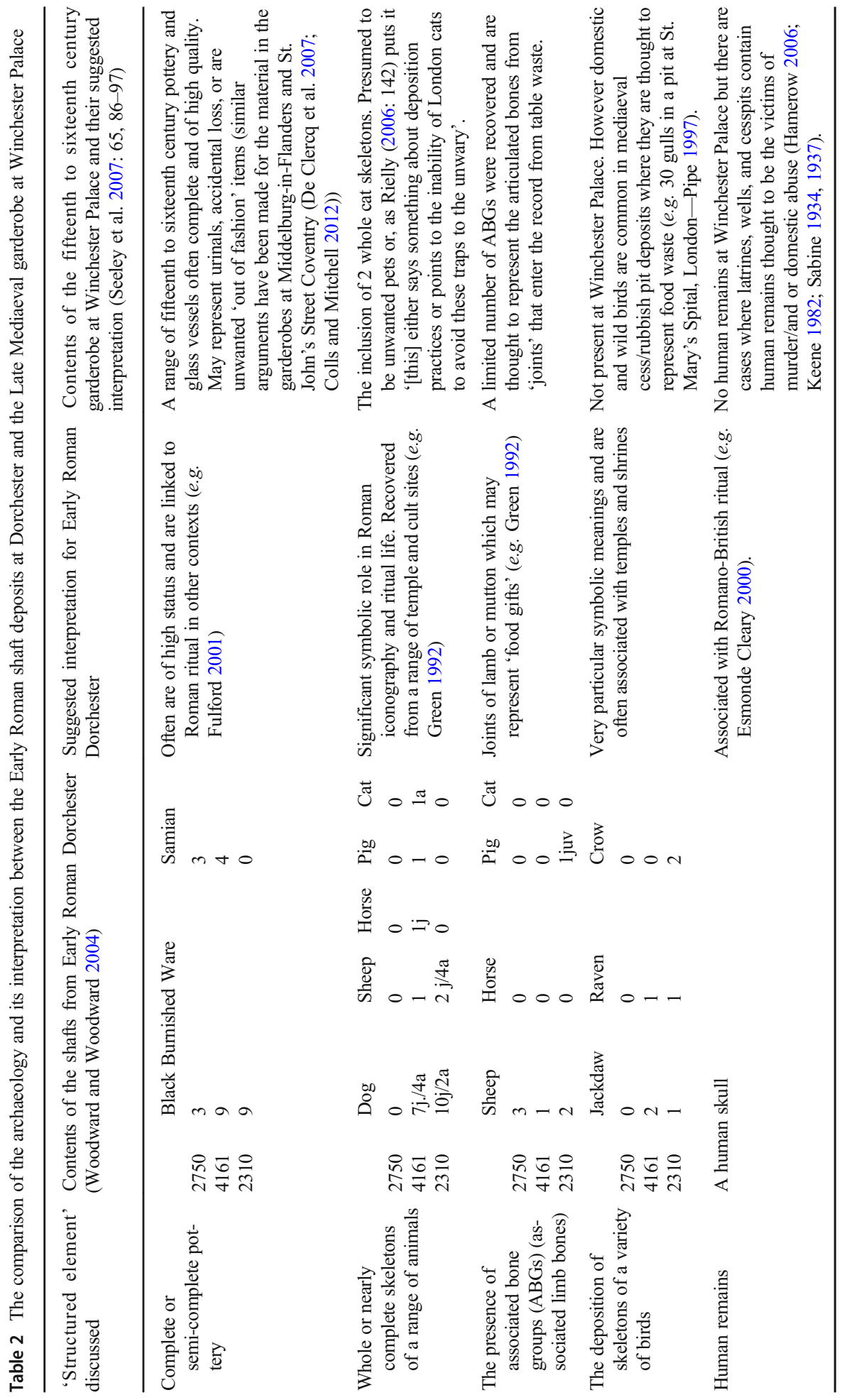




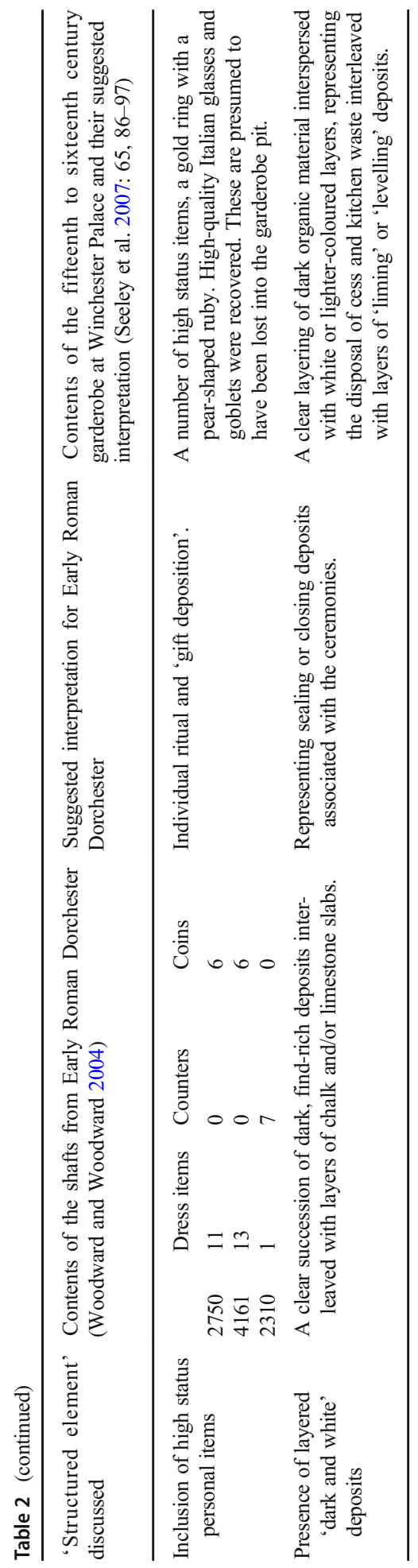


structure, and archaeological interpretation can be quite diverse. Assumption bedevils the archaeology and interpretation of such features; for example, barrel-lined or timberlined latrines may have been misidentified as 'wells' in past UK excavations. These features therefore warrant proper excavation, rather than onsite 'avoidance' (regardless of what their ultimate function(s) may have been), since not doing so risks loss of vital information and ultimately interpretation.

One solution to any such oversight is to correctly identify and understand the lives of cesspits/latrines through intensively recording and sampling these features during excavation. A combined multi-proxy analysis of the material culture and the biological remains preserved in such features can lead to detailed understanding of waste disposal, diet, and status in settlements. A more biographical approach incorporating detailed excavation and recording clearly has great potential, as seen in the examples of the US approach to these features (see discussion in "Life Stage 4"). Reference to the existing body of modern and historical evidence on the construction of these features also can improve recognition of cesspits/latrines in the archaeological record. The chronological period of excavation should not override the possibility that a deposit is a cesspit/latrine or, indeed, something of a more specific nature (e.g. the different interpretations of similar data from Roman Greyhound Yard, Dorchester, vs. Mediaeval Winchester Palace, London). The full suite of finds (artefactual and biological) should drive interpretation as much as the nature of the feature itself (see also Smith 2012). Finally, we need to reconsider why more recent (e.g. Post-Mediaeval to nineteenth century) features often go ignored, simply just because they are 'more recent' and from historically well-recorded periods?

The question for all of us, in future, is whether we can afford to assume that we already fully understand these features, regardless of their date? This present paper and a previous survey (Smith 2012) of UK cesspits should, at the very least, outline the benefits of the better recording of archaeological and environmental evidence from these features.

Acknowledgements Several colleagues have very generously provided the author with pre-publication material for a number of the sites examined. This includes Anne Davies (Museum of London Archaeology), Kevin Colls (Staffordshire University), Ben Gearey (University College, Cork) and Emma Hopla (Atkins), Angela Monkton and Anita Radini (both formerly University of Leicester Archaeology Service), James Rackham (Environmental Archaeology Consultancy), and Rebecca Nicolson and Richard Brown (Oxford Archaeology South).

Various versions of this text were read by Wendy Smith and Henry Chapman (both from University of Birmingham), as well as Harry Kenward (University of York). I am grateful to Simon Esmonde Cleary (University of Birmingham) for the loan of some vital texts to support this research and his comments on an earlier draft of this text. I also want to thank members of the CAHA Research Reading Group for their comments on the first draft of this text. This paper was radically improved by the comments of a number of referees, which led to an extensive rewrite. One referee, in particular, not only raised the issue of how research on these features occurred in the USA but also sent along three separate sets of additional references.

This paper was researched and drafted whilst on academic study leave funded by the College and Arts and Law, University of Birmingham. Figures 1 and 2 were prepared by Henry Buglass (formerly College of Arts and Law, University of Birmingham). I understand from Henry Buglass that we all owe thanks to Graeme Norrie (also formerly College of Arts and Law, University of Birmingham), who served as the model for Fig. 2.

\section{Compliance with Ethical Standards}

Competing Interests The author declares that he has no competing interest. 
Open Access This article is licensed under a Creative Commons Attribution 4.0 International License, which permits use, sharing, adaptation, distribution and reproduction in any medium or format, as long as you give appropriate credit to the original author(s) and the source, provide a link to the Creative Commons licence, and indicate if changes were made. The images or other third party material in this article are included in the article's Creative Commons licence, unless indicated otherwise in a credit line to the material. If material is not included in the article's Creative Commons licence and your intended use is not permitted by statutory regulation or exceeds the permitted use, you will need to obtain permission directly from the copyright holder. To view a copy of this licence, visit http://creativecommons.org/licenses/by/4.0/.

\section{References}

Addyman, P. (1989). The archaeology of public health at York. England. World Archaeology, 21, $244-264$. Allen, M. J. (1993). Mineralised coprolites and cess. In Woodward, P., Davies S. M., \& Graham, A. H. (Eds.), Excavations at Greyhound Yard, Dorchester 1981-1984 (Dorset Natural History and Archaeological Society Monograph Series Number 12) (pp. 348), Dorchester: Dorset Natural History and Archaeology Society.

Barber, B., \& Thomas, C. (2002). The London Charterhouse (Museum of London Archaeology Service Monograph 10). London: Museum of London Archaeology Service.

Berggren, A. (2012). The interpretation of depositions in pits. Is it time for the pendulum to swing back? Archaeological Dialogues, 19, 116-120.

Bradley, R., \& Edmonds, M. (1993). Interpreting the axe trade. Cambridge: Cambridge University Press.

Buckland, P. C. (1980). Insect remains from the well. In I. M. Stead (Ed.), Rudston Roman Villa (pp. 162167). Leeds: Yorkshire Archaeological Society.

Burch, M., Treveil, P., \& Keene, D. (2011). The development of early medieval and later Poultry and Cheapside: excavations at 1 Poultry and vicinity, city of London (MoLA Monograph Series 38). London: Museum of London Archaeology Service.

Burström, N. M. (2014) Things in the Eye of the Beholder: a Humanistic Perspective on Archaeological Object Biographies, Norwegian Archaeological Review, 47, 65-82.

Bush, D. R. (2000). Interpreting the latrines of the Johnson's Island Civil War Military Prison. Historical Archaeology, 34, 62-78.

Calvert, P. (2014) 'Technical information online: Compost toilets' Practical Action. https://answers. practicalaction.org/our-resources/item/compost-toilets. Accessed 01/06/2020.

Caruthers, W. \& Smith, D. (2020). Mineralised plant and insect remains: a guide to the identification of calcium phosphate replaced remains. Historic England. https://historicengland.org.uk/imagesbooks/publications/mineralised-plant-and-invertebrate-remains/. Accessed 22/04/2020.

Carnes-McNaughton, L. F., \& Harper, T. M. (2000). The parity of privies: summary research on privies in North Carolina. Historical Archaeology, 34, 97-110.

Cessford, C. (2017). Throwing away everything but the kitchen sink? Large assemblages, depositional practice and post-medieval households in Cambridge. Post-Medieval Archaeology, 51, 164-193.

Chapman, J. (2012). Structured deposition meets deliberate object fragmentation. Archaeological Dialogues, $19,133-144$.

Ciecieznski, N. J. (2013). The stench of disease: public health and the environment in Late-Medieval English towns and cities. Health, Culture and Society, 4, 92-104.

Coope, G. R., \& Osborne, P. J. (1968). Report on the coleopterous fauna of the Roman well at Barnsley Park, Gloucestershire. Transactions of the Bristol and Gloucestershire Archaeological Society, 86, 84-87.

Colls, K., \& Mitchell, W. (2012). A cycle of recession and recovery AD 1200-1900: archaeological investigations at Much Park Street, Coventry (British Archaeological Reports, British Series). Oxford: Archaeopress.

Crane, B. D. (2000). Filth, garbage, and rubbish: refuse disposal, sanitary reform, and Nineteenth-century yard deposits in Washington DC. Historical Archaeology, 34, 20-38.

de Clercq, W., Caluwé, D., Cooremans, B., de Buyser, F., de Groote, K., Deforce, K., Ervynck, A., Lentacker, A., Mortier, S., Pype, P., Vandenberghe, S., van Neer, W., \& Wouters, H. (2007). Living in times of war: waste of c. $1600 \mathrm{AD}$ from two garderobe chutes in the castle of Middelburg-in-Flanders (Belgium). PostMedieval Archaeology, 41, 1-63. 
Del Porto, D., \& Steinfeld, C. (1999). The composting toilet system book: a practical guide to choosing, planning and maintaining composting toilets, a water-saving, pollution-preventing wastewater alternative. Concord: Centre for Ecological Pollution Prevention.

Department of Water Affairs South Africa - DWAFSA (2002). Sanitation for a healthy nation. Sustainable Sanitation Alliance https:/www.susana.org/en/knowledge-hub/resources-and-publications/library/details/ 931 Accessed 25th of October 2018.

Douglas, M. (1966). Purity and danger: an analysis of concepts of pollution and taboo. London and New York: Routledge.

Edmonds, M. (2012). Biographies and Afterlives. In A. M. Jones \& J. Gardiner (Eds.), Image, memory \& monumentality: archaeological engagements with the material world: a celebration of the academic achievements of Professor Richard Bradley (pp. 146-162). Oxford: Oxbow Books.

Esmonde Cleary, S. (2000). Putting the dead in their place: burial location in Roman Britain. In J. Pearce, M. Millet, \& N. Struck (Eds.), Burial, Society, Context in the Roman World (pp. 127-142). Oxford: Oxbow Books.

Evans, D. (2010). A good riddance of bad rubbish? Scatological musings on rubbish disposal and the handling of 'filth' in medieval and early post-medieval towns. In K. De Groote, D. Tys, \& M. Pieters (Eds.), Exchanging Medieval Material Culture: Studies on archaeology and history presented to Frans Verhaeghe (Relicta Monografieën 4, Archeologie, Monumenten- en Landschapsondersoek in Vlaanderen) (pp. 267-278). Brussels: Flemish Heritage Institute.

Evans, J. G. (2003). Environmental archaeology and the social order. New York: Routledge.

Fontijn, D. (2012). Meaningful but beyond words? Interpreting material culture patterning. Archaeological Dialogues, 19, 124-127.

Fulford, M. (2001). Links with the past; pervasive 'ritual' behaviour in Roman Britain. Britannia, 32, 199218.

Garrow, D. (2012). Odd deposits and average practice. A critical history of the concept of structured deposition. Archaeological Dialogues, 19, 85-115.

Graham, J., \& Polizzotto, M. L. (2013). Pit latrines and their impacts of groundwater quality: a systematic review. Environmental Health Perspectives, 12, 521-530.

Grassrootswiki (2010). 'Single pit systems' Grassrootswiki. http://grassrootswiki.org/index.php/Single_pit_ system. Accessed 18/11/2010.

Greig, J. R. (1981). The investigation of a Medieval barrel-latrine from Worcester. Journal of Archaeological Science, 8(265-282), 3.

Greig, J. R. A. (1982). Garderobes, sewers, cesspits and latrines. Current Archaeology, 85, 49-52.

Green, M. J. (1992). Animals in Celtic life and myth. London: Routledge.

Gosden, C., \& Marshall, M. (1999). The cultural biography of objects. World Archaeology, 31, 169-178.

Hakbij1, T., \& De Groot, M. (1997). Insect remains from Willem Barents' 1596 Arctic exploration preserved in "Het Behouden Huys", Novaya Zemlya-with notes on the medicinal use of cantharides. Quaternary Proceedings, 5, 129-134.

Hall, A. R., Kenward, H. K., \& Williams, D. (1980). Environmental evidence from roman deposits in Skeldergate (Archaeology of York 14/3). London: Council for British Archaeology.

Hall, R. A., McGregor, H., \& Stockwell, M. (1988). Medieval tenements and other sites (Archaeology of York: The Medieval walled city North East of the Ouse - AY10/02). London: Council for British Archaeology.

Hall, R. A., \& Hunter-Mann, K. (2002). Medieval urbanism at Coppergate: refining a townscape. (Archaeology of York: The Medieval walled city North East of the Ouse - AY10/06). London: Council for British Archaeology.

Hamerow, H. (2006). 'Special deposits' in Anglo-Saxon settlements. Medieval Archaeology, 50, 1-30.

Hamilton-Dyer, S. (1993). Fish remains. In P. Woodward, S. M. Davies, \& A. H. Graham (Eds.), Excavations at Greyhound Yard, Dorchester 1981-1984 (Dorset Natural History and Archaeological Society Monograph Series Number 12) (pp. 245-247). Dorchester: Dorset Natural History and Archaeology Society.

Hill, J. D. (1995). Ritual and rubbish in the Iron Age of Wessex (British Archaeological Reports, British Series 242). Oxford: Tempus Reparatum.

Holtorf, C. J. (1998). The life-histories of megaliths in Mecklenburg-Vorpommern (Germany). World Archaeology, 30, 23-38.

Holtorf, C. (2002). Notes on the life history of a potsherd. Journal of Material Culture, 7, 49-71.

Hummperetz, W. 2010. Micro history, archaeology and the study of housing culture. Some thoughts on archaeological and historical data from a cesspit in 17th-century Breda. In De Groote, K., Tys, D. \& Pieters, M. (Eds.) Exchanging medieval material culture: studies on archaeology and history presented to 
Frans Verhaeghe (Relicta Monografieën 4, Archeologie, Monumenten- en Landschapsondersoek in Vlaanderen) (pp. 2792-84). Brussels: Flemish Heritage Institute.

Immonen, V. (2002). Functional ladles or ceremonial cutlery?A cultural biography of prehistoric wooden spoons from Finland. Acta Borealia, 19, 27-47.

Jeffries, N. (2006). The Metropolis Local Management Act and the archaeology of sanitary reform in the London Borough of Lambeth 1856-86. Post Medieval Archaeology, 40, 272-290.

Jenkins, J. (2005). The humanure handbook: a guide to composting human manure (3rd ed.). White River Junction, Vermont: Chelsea Green Publishing.

Jenkins, M., \& Curtis, V. (2005). Achieving 'the good life': why some people want latrines in rural Benin. Social Science and Medicine, 61, 2446-2459.

Jervis, B. (2014). Middens, memory and the effect of waste Beyond symbolic meaning in archaeological deposits. An early medieval case study. Archaeological Dialogues, 21, 175-196.

Jones J. (2010). Plant macrofossil remains from Finzel's Reach, Bristol (Unpublished report to Oxford Archaeology).

Jones, J., \& Straker, V. (1989). Greyhound Yard, Dorchester, Dorset, 1984: macroscopic plant remains. Ancient Monuments Laboratory Research reports (new series) 42/1989. London: English Heritage.

Jones, J., \& Straker, V. (1993). The macroscopic plant remains. In P. Woodward, S. M. Davies, \& A. H. Graham (Eds.), Excavations at Greyhound Yard, Dorchester 1981-1984 (Dorset Natural History and Archaeological Society Monograph Series Number 12) (pp. 349-350). Dorchester: Dorset Natural History and Archaeology Society.

Jørgensen, D. (2006). Medieval latrines and the law. Medium Aevum Quotidianum, 53, 5-16.

Joy, J. (2009). Reinvigorating object biography: reproducing the drama of object lives. World Archaeology, $41,540-556$.

Keene, D. J. (1982). Rubbish in Medieval Towns. In A. R. Hall \& H. K. Kenward (Eds.), Environmental archaeology in the urban context (Council for British Archaeology Research Report 43) (pp. 26-30). London: Council for British Archaeology.

Kenward, H. K. (1978). The analysis of archaeological insect assemblages: a new approach. (Archaeology of York, 19/1). London: Council for British Archaeology.

Kopytoff, I. (1986). The cultural biography of things: commoditization as process. In A. Appadurai (Ed.), The social life of things: commodities in cultural perspective (pp. 64-91). Cambridge: Cambridge University Press.

La Motta, V., \& Schiffer, M. (2001). Behavioural archaeology. toward a new synthesis. In I. Hodder (Ed.), Archaeological Theory Today (pp. 14-64). Cambridge: Polity.

Maltby, M. (1990). The animal bones from the Romano-British deposits at the Greyhound Yard and Methodist Chapel Sites in Dorchester, Dorset. In Ancient Monuments Laboratory Reports (new series) 9/1990. London: English Heritage.

Maltby, M. (1993). Animal bones. In P. Woodward, S. M. Davies, \& A. H. Graham (Eds.), Excavations at Greyhound Yard, Dorchester 1981-1984 (Dorset Natural History and Archaeological Society Monograph Series Number 12) (pp. 315-340). Dorchester: Dorset Natural History and Archaeology Society.

McCarthy, J. P., \& Ward, J. A. (2000). Sanitation practices, depositional processes, and interpretive contexts of Minneapolis privies. Historical Archaeology, 34, 111-129.

McCobb, L. M. E., Briggs, D. E. G., Hall, A. R., \& Kenward, H. K. (2004). The preservation of invertebrates in 16th-century cesspits at St Saviourgate York. Archaeometry, 46(157-69), 1.

Morgan, P. (2007). Toilets that make compost low-cost: sanitary toilets that produce valuable compost for crops in an African context. Aquamor: Harare, Zimbabwe/ Stockholm Environment Institute/ EcoSanRes Programme. ecosanres.org/pdf_files/ToiletsThatMakeCompost.pdf Accessed 25/10/2019.

Mytum, H. (2004). Artefact biography as an approach to material culture: Irish gravestones as a material form. The Journal of Irish Archaeology, 12(13), 111-127.

Nakagiri, A., Kulabako, R. N., Nyenje, P., Tumuhairwe, J. B., Niwagaba, C., \& Kansiime, F. (2015). Performance of pit latrines in Urban poor areas: a case of Kampala Uganda. Habitat International, 49, 529-537.

Nakagiri, A., Niwagaba, C., Nyenje, P., Kulabako, R. N., \& Tumuhairwe, J. B. (2016). Are pit latrines in urban areas of Sub-Saharan Africa performing? A review of the usage, infilling, insects and odour nuisances. BMC Public Health, 16, 120.

Osborne, P. J. (1983). An insect fauna from a modern cesspit and its comparison with probable cesspit assemblages from archaeological sites. Journal of Archaeological Science, 10, 453-463. 
Panagiotakopulu, E. (2000). Archaeology and entomology in the Eastern Mediterranean. In Research into the history of insect synanthropy in Greece and Egypt (British Archaeological Reports, International Series 836). Oxford: British Archaeological Report.

Patrick, C., \& Ratkai, S. (2009). The bullring uncovered: excavations at Edgbaston Street, Moor Street, Park Street and the Row, Birmingham 1997-2001. Oxford: Oxbow Books.

Peña, E. S., \& Denmon, J. (2000). The social organization of a boardinghouse: archaeological evidence from the Buffalo waterfront. Historical Archaeology, 34, 79-96.

Pipe, A. (1997). Animal bone. In C. Thomas, B. Sloane, \& C. Philpotts (Eds.), Excavations at the priory and hospital of St. Mary Spital, London (Museum of London Archaeology Service Monograph 1) (pp. 231234). London: Museum of London Archaeology Service.

Richards, C., \& Thomas, J. (1984). Ritual activity and structured deposition in Later Neolithic Wessex. In R. Bradley \& J. Gardiner (Eds.), Neolithic studies: a review of some current research (British Archaeological Reports, British Series 133) (pp. 189-218). Oxford: British Archaeological reports.

Rielly, K. (2006). The animal bone. In D. Seeley, C. Phillpotts, \& M. Samuel (Eds.), Winchester Palace: excavations at the Southwark Residence of the Bishops of Winchester (Museum of London Archaeology Service Monograph 31) (pp. 130-141). London: Museum of London Archaeology Service.

Rogers, J. (1993). The human remains. In P. Woodward, S. M. Davies, \& A. H. Graham (Eds.), Excavations at Greyhound Yard, Dorchester 1981-1984 (Dorset Natural History and Archaeological Society Monograph Series Number 12) (pp. 314-315). Dorchester: Dorset Natural History and Archaeology Society.

Routray, P., Schmidt, W.-P., Boisson, S., Clasen, T., \& Jenkins, M. W. (2015). Socio-cultural and behavioural factors constraining latrine adoption in rural coastal Odisha: an exploratory qualitative study. BMC Public Health, 15, 880 .

Sabine, E. L. (1934). Latrines and cess pools of Medieval London. Speculum, 9, 304-321.

Sabine, E. L. (1937). City cleaning in Medieval London. Speculum, 12, 19-43.

Sara, S., \& Graham, J. (2014). Ending open defecation in Rural Tanzania: which factors facilitate latrine adoption? International Journal of Environmental Research and Public Health, 11, 9854-9870.

Seeley, D., Phillpotts, C., \& Samuel, M. (2007). Winchester Palace: excavations at the Southwark Residence of the Bishops of Winchester (Museum of London Archaeology Service Monograph 31). London: Museum of London Archaeology Service.

Sharpe, R. (1900). Folio 115B [facieinversa.] (xix). In Sharpe, R. (Ed.) Calendar of letters relating to period c.1275-c.1312, preserved at the Guildhall B (p. 277). London: Corporation of the City of London, His Majesty's Stationary Office.

Signe Morrison, S. (2008). Excrement in the Late Middle Ages: sacred filth and Chaucer's fecopoetics. London: Palgrave Macmillan.

Simpson, T. (2001). The Roman well at Piddington, NorthamptonshireEngland: an investigation of the insect fauna. Environmental Archaeology, 6, 91-96.

Skidmore, P. (1999). The Diptera. In A. Connor \& R. Buckley (Eds.), Roman and Medieval occupation in Causeway Lane, Leicester (Leicester Archaeological Monographs 5) (pp. 341-343). Leicester: Leicester University Press.

Smith, D. (2009a). Chapter 14: the insect remains from Edgbaston and Park Street. In C. Patrick \& S. Ratkai (Eds.), The bulling uncovered: excavations at Edgbaston Street, Moor Street, Park Street and the Row, Birmingham 1997-2001 (pp. 269-275). Oxford: Oxbow Books.

Smith, D. N. (2009b). Mineralised and waterlogged fly pupae, and other insects and arthropods from Southampton French Quarter 1382 (Specialist Report Download E9). Oxford Archaeology, Oxford http://library.thehumanjourney.net/52/1/SOU_1382_Specialist_report_download_E9.pdf. Accessed 8th of November 2019.

Smith, D. N. (2010). The insect remains from Finzel's Reach Bristol. (Unpublished report to Oxford Archaeology South). Birmingham: University of Birmingham.

Smith, D. N. (2012). Defining an 'indicator package' to allow identification of 'cess pits' in the archaeological record. Journal of Archaeological Science, 40, 526-543.

Smith, R. S., \& Davies, S. (1993). Roman pottery. In P. Woodward, S. M. Davies, \& A. H. Graham (Eds.), Excavations at Greyhound Yard, Dorchester 1981-1984 (Dorset Natural History and Archaeological Society Monograph Series Number 12) (pp. 202-289). Dorchester: Dorset Natural History and Archaeology Society.

Smith, K. G. V. (1973). Insects and other arthropods of medical importance. London: British Museum (Natural History).

Smith, K. G. V. (1989). An introduction to the immature stages of British flies (Handbooks for the identification of British Insects Vol. 10 part 14). London: Royal Entomological Society of London. 
Solidarities (2017) Access to latrine construction Solidarites. Org https:/www.solidarites.org/wpcontent/uploads/2017/10/Access-to-sanitation-latrine-construction-SOLIDARITES-INTERNATIONAL. pdf. Accessed 8th of November 2019.

Stottman, M. J. (2000). Out of sight, out of mind: privy architecture and the perception of sanitation. Historical Archaeology, 34, 39-61.

Tilley, E., Lüthi, C., Morel, A., Zurbrügg, C., \& Schertenleib, R. (2008). Compendium of sanitation systems and technologies. Dübendorf: Swiss Federal Institute of Aquatic Science and Technology (Eawag).

Thomas, J. (1990). Silent running: the ills of environmental archaeology. Scottish Archaeological Review, 7, 2-7.

Thomas, J. (2012). Some deposits are more structured than others. Archaeological Dialogues, 19, 127-129.

Tringham, R. (1994). Engendered places in prehistory. Gender, Place and Culture, 1, 169-203.

US Army. (1945). Field hygiene and sanitation (US Army Field Manual 21-10). ibiblio.org website http://www.ibiblio.org/hyperwar/USA/ref/FM/index.html. Accessed 15th of October 2019.

US Army. (2005). Field facilities for human waste disposal. Armystudyguide.com http://www. armystudyguide.com/content/army_board_study_guide_topics/field_sanitation/field-facilities-for-huma. shtml accessed 15 th of October 2018.

US Army. (2007). Field hygiene and sanitation (US Army Field Manual 21-10). Massachusetts: US Army.

Van Oosten, R. (2016). The Dutch great stink: the end of the cesspit era in pre-industrial towns of Leiden and Haarlem. European Journal of Archaeology, 19, 704-727.

Water Policy International. (2001). Ecological sanitation water page.org http://www.africanwater.org/ecosan main.htm Accessed 15th of October 2018.

Wheeler, K. (2000). Theoretical and methodological considerations for excavating privies. Historical Archaeology, 34, 3-19.

Woodward, P., Davies, S. M., \& Graham, A. H. (1993). Excavations at Greyhound Yard, Dorchester 19811984 (Dorset Natural History and Archaeological Society Monograph Series Number 12). Dorchester: Dorset Natural History and Archaeology Society.

Woodward, P., \& Woodward, A. (2004). Dedicating the town: urban foundation deposits in Roman Britain. World Archaeology, 36, 68-86.

World Health Organisation - WHO (2010). Introduction to fact sheets on sanitation. World Health Organisation. http://www.who.int/water_sanitation_health/emergencies/envsanfactsheets/en/index $2 . h t m l$ Accessed 15th of October 2019.

Publisher's Note Springer Nature remains neutral with regard to jurisdictional claims in published maps and institutional affiliations. 